\title{
数值解析結果に基づく鋼梁の骨格曲線算定式の導出 EQUATION DISCOVERY FOR SKELTON CURVE OF STEEL BEAM USING NUMERICAL ANALYSIS RESULTS
}

\author{
鈴 木 环 也*1 \\ Takuya SUZUKI
}

\begin{abstract}
The purpose of this study is to verify the applicability of the equation discovery method proposed using mode extraction via singular value decomposition to the problem of finding a simple mathematical expression representing an input/output system of numerical analysis results. In this study, the derivation of equations for skeleton curve of steel beam was verified as an example. First, the outline of equation discovery method and the example problem are explained. Then, the results of the equation discovery are shown, and the applicability of the method is verified.
\end{abstract}

Keywords : Equation discovery, Skelton curve, Steel beam

関数同定，骨格曲線，鋼梁

\section{1. はじめに}

近年の計算機能力の向上に伴う数值解析技術の発展は著しく，複 雑かつ詳細な解析モデルを用いた解析が多く行われるようになって きている例えば 1)。ただし，これらの解析には多くの計算時間を要す るため，実際の設計現場が求めるスピードには応えられないという 課題がある。そのような課題に対して, 予め実施した数多くの解析 結果を教師データとして，ニューラルネットワークを用いてシミュ レーション解析の入出カシステムを模擬する予測機を構築し, 詳細 モデルと同等の精度を持った高速なシミュレーション解析を行う研 究も行われている例えば2)3)。これらの予測機は帰納的にモデル化され ているために一定の誤差は含むものの, 詳細モデルの結果と高精度 に整合する結果を高速に算出できることが確認されている。

しかしながら，ニューラルネットワークによって模擬される入出 カシステムは当然複雑なものとなり, システムとしては完全に数式 化されてはいるものの, 利用者側にとってはブラックボックス的な 認識とならざるを得ない。また，このニューラルネットワークを指 針等の計算例に載せることも現実的に不可能であることから，これ らを実際の設計に利用できる設計者，それを確認できる審査者は限 定される。

著者は, 設計者がこれらの模擬された入出力システムを容易に利 用できるようにするためには，この入出力システムを単純化された 数式で表現することが重要であると考えている。もし, 設計者が必 要とする情報（例えば, Fig.1 に示寸荷重変位関係の折れ点など）が 単純な計算式の形で陽に与えられれば，指針等への記載が可能とな

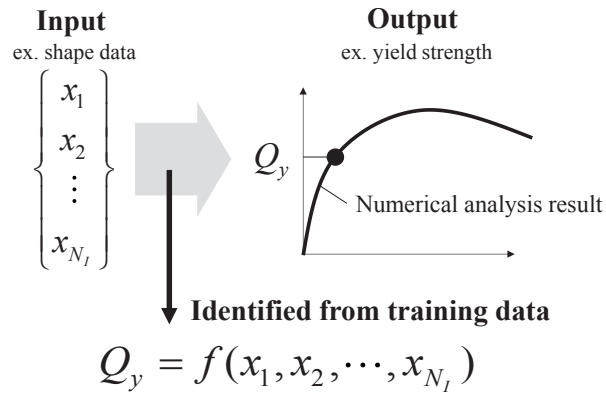

Fig. 1 Equation discovery using numerical analysis results

り，既に記載されている多くの設計式と同様に表計算ソフトを使つ て設計者が計算することも，計算結果の妥当性を審査者が確認する ことも可能になり非常に有意義である。そのため著者は，教師デー タとして与えられた入出力結果から，その関係を数式の形で同定す る手法を提案し，例題を通してその効果を検証している。ただし， 文献 4 では関係式が既に判明している梁の撓み式の導出を例題とし て用いており，数值解析結果のように同定対象とする関係式が未知 であるような問題に対しての適用性や課題については不明な点が多 い。

そこで，本研究においては，文献 4 の手法により，事前に実施し た数值解析の入出力システムを単純な数式の形で表現できるから゙う かを，フレーム解析に用いる部材特性算出を想定した鋼梁の骨格曲 線算定式の導出を例題として検証する。まず，関数同定手法の概要

*1 竹中工務店技術研究所 主任研究員 - 博士 (工学)

Chief Researcher, R\&D Institute, Takenaka Corporation, Dr.Eng. 
を説明するとともに，例題とする関数同定問題について説明する。 つづいて, 関数同定結果を示し, 同定手法の適用性を検証する。 なお, 本関数同定手法においては, 事前に実施するシミュレーシ ヨン解析が真の挙動を表現できることが必要不可欠であるが, 本研 究において用いるシミュレーション解析は正しいことを前提として, 同定手法の検証を行う。

\section{2. 数値解析結果に基づく算定式の導出}

\section{1 算定式導出の概要}

本節では, 本研究で実施する数值解析結果に基づく算定式の導出 の全体の流れについて説明する。Fig.2 には導出のフローの全体像を, 以降ではフロー内の各処理について説明する。

(1)まず，算定式によって算定するパラメータおよび算定式の入力変 数とするパラメータを設定する。なお，入力パラメータについて は可変範囲も併せて設定する。この範囲が数式の適用範囲となる。 (2)つづいて, 設定した入力パラメータを変化させて, 数值解析を行 い, 各入力条件における出力パラメータの教師データを作成する。 教師データの数については, (1)で設定した範囲内において偏りの ないように十分な数を用意する。この教師データ数および選び方 の妥当性については(5)において検証データを用いて検証する。

(3)算定式の構成および未知係数を定める。今回のように真の算定式 が未知の場合, 算定式が様々な形を取れるように構成, 未知係数 を定める必要がある。

(4)教師データを再現できる（すなわち誤差が小さくなる）ような未 知係数を探索する。本研究では, 未知係数を可能な限り少なくす る目的で, 探索する手法には, モーダル反復誤差修正法を改良し た文献 4 の手法を用いる。

(5)同定された未知係数の妥当性を検証する。具体的には教師データ の再現精度を確認するとともに, 教師データとして学習に利用し ていない検証用のデータセットを用意し, その精度についても確 認する。

\section{2 算定対象とする骨格曲線の特性值と適用範囲}

本研究で算定対象とする骨格曲線は, 局部座屈等の影響が小さな FA ランク 5) $0 \mathrm{H}$ 型断面の片持梁に作用するせん断力 $Q$ と変形角 $\theta$ の 関係を模擬するトリリニアモデルとする。このトリリニアモデルの 降伏荷重 $Q_{y}$, 最大荷重 $Q_{\text {max }}$, 最大荷重時の変形角 $\gamma_{\text {max }}$ および変形角 $1 / 20 \mathrm{rad}$ 時の荷重 $Q_{0.05 \mathrm{rad}}$ ，の 4 種の算定式の導出を行う（Fig.3）。弾 性剛性 $K$ は片持ち梁の理論式において一定の精度で計算可能である ため, この 4 種の数值の算定式から, 荷重変位関係における第一折 点 $\left(Q_{y} / K, Q_{y}\right)$, 第二折点 $\left(\gamma_{\max }, Q_{\max }\right)$, 第三折点 $\left(0.05, Q_{0.05 \mathrm{rad}}\right)$ を定めることが可能となる。一般的に解析に用いられるトリリニア モデルは負勾配を有さないが, 部材の骨格曲線を劣化挙動も含めて 推定できるかを確認することは終局挙動評価への展開を図る上で重 要と考え, 劣化勾配を評価しうる上記の折点の設定を行っている。

算定式導出の対象とする $\mathrm{H}$ 型断面梁の適用範囲は, 梁成 $H=400 \sim$ $800 \mathrm{~mm}$, 梁幅 $B=200 \sim 350 \mathrm{~mm}$, ウェブ厚 $t_{w}=12 \sim 24 \mathrm{~mm}$, フランジ厚 $t_{f}=16 \sim 24 \mathrm{~mm}$, 梁長さ $L=2000 \sim 8000 \mathrm{~mm}$ の範囲内にあり, フランジ 幅厚比 $\alpha_{f}$ は 8.08 以下かつウェブ幅厚比 $\alpha_{w}$ は 36.6 以下を満たすもの とする。なお, 簡便のため, フランジ幅厚比やウェブ幅厚比は, 板 厚を考慮しない以下の略算式で計算する。

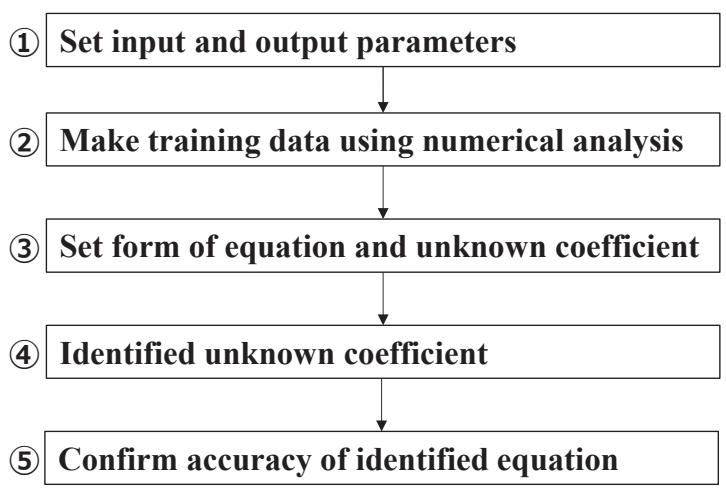

Fig. 2 Flow of equation discovery using numerical analysis results

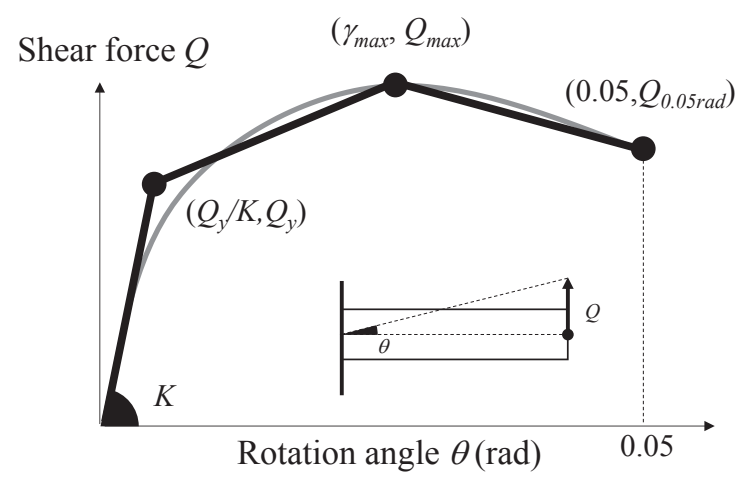

Fig. 3 Tri-linear curve for load-displacement relationship

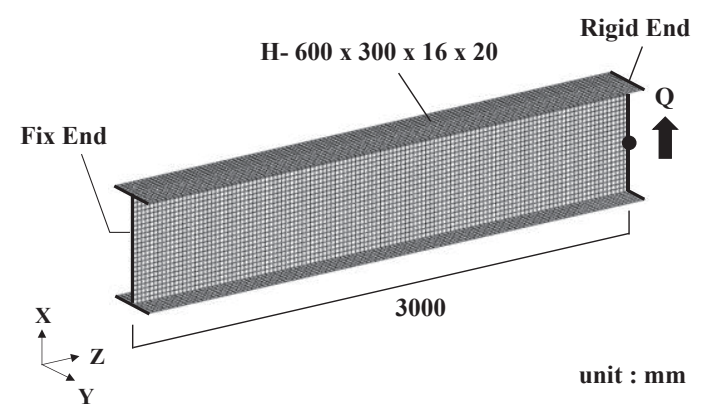

Fig.4 Analytical Model (H-600x300x16x20)

$\alpha_{f}=B / 2 t_{f}$

$\alpha_{w}=H / t_{w}$

\section{3 教師データの作成条件}

本節では数式導出に用いる教師データを作成する数值解析の条件 を説明する。

教師データは, 適用範囲内にある寸法の $\mathrm{H}$ 形断面梁の有限要素解 析を実施して荷重変位関係を算出し，その荷重変位関係から前節で 示した $Q_{y}, Q_{\max }, \gamma_{\max }, Q_{0.05 \mathrm{rad}}$ の 4 種のデータを取り出して作成する。 なお， $Q_{y}$ については，接線剛性が初期剛性の $1 / 3$ になった時点の荷 重值とする。

解析には汎用有限要素法解析プログラム ABAQUS を用い, 幾何 学的非線形および材料非線形を考慮する。Fig.4 には一例として, H-600x300x16x20，L=3000mm の解析モデル図を示す。要素は 4 節 点積層シェル要素 $(\mathrm{S} 4)$ を用い, 層数は 5 層, シェル面内の積分点数 
は 1 の低減積分要素とする。またメッシュの寸法は $25 \mathrm{~mm} \times 25 \mathrm{~mm}$ の正方形を基本として設定する。解析に用いる鋼材の非線形特性は, 移動硬化型のバイリニアとする。Table1 に鋼材の機械的性質を示す。 本検討では板厚によらず, ヤング率 $E$ は $205 \mathrm{GPa}$, ポアソン比梳 0.3 , 降伏応力度 $\sigma_{y}$ は $325 \mathrm{MPa}$ とする。なお解析の安定化のために, 降伏 後の硬化勾配は $1 / 1000$ とする。境界条件は梁端部を完全固定条件の 片持梁とし, 他端断面に剛体要素を設定した上で, 強制変位を回転 角 $1 / 20 \mathrm{rad}$ まで作用させる。また, 先行して座屈固有值解析を実施 し, 得られる 1 次モードおよび 2 次モードに対して, モードの最大 変位量がウェブ厚の $3 \%$ となるよう形状初期不整を導入する。

Table2 には教師データ作成に用いる解析モデルの寸法一覧を示す。 モデルの寸法は, 2.2 節で設定した適用範囲内にある寸法を網羅的 に設定している。なお, 幅厚比規定が FA ランクとならない寸法に ついては教師データから除外する。結果として, 教師データ作成の ために実施する解析数は 420 となる。これらの解析結果に基づいて, 各 $\mathrm{H}$ 型断面梁の $Q_{y}, Q_{\max }, \gamma_{\max }, Q_{0.05 \text { rad }}$ の 4 種のデータの算定式を 導出するための教師データが得られる。

\section{4 算定式の構成と未知係数}

本節では, 算定式の構成と同定対象とする未知係数について説明 する。 $\mathrm{H}$ 型断面梁の $Q_{y}, Q_{\max }, \gamma_{\max }, Q_{0.05 \mathrm{rad}}$ の算定式は, 文献 4 の形 式を参考にそれぞれ下記のように設定する。式中, べき乗数 $p_{i j}$ およ び重み $w_{i}$ が数式の未知係数であり, 同定対象である。

$$
\begin{aligned}
& Q_{y}=Q_{p} \cdot\left(\sum_{i=1}^{6} w_{i} \cdot\left(\frac{B}{H}\right)^{p_{i 1}} \cdot\left(\frac{B}{2 t_{f}}\right)^{p_{i 2}} \cdot\left(\frac{H}{t_{w}}\right)^{p_{i 3}} \cdot\left(\frac{L}{H}\right)^{p_{i 4}}\right) \\
& Q_{\max }=Q_{p} \cdot\left(\sum_{i=1}^{6} w_{i} \cdot\left(\frac{B}{H}\right)^{p_{i 1}} \cdot\left(\frac{B}{2 t_{f}}\right)^{p_{i 2}} \cdot\left(\frac{H}{t_{w}}\right)^{p_{i 3}} \cdot\left(\frac{L}{H}\right)^{p_{i 4}}\right) \\
& Q_{0.05 \mathrm{rad}}=Q_{p} \cdot\left(\sum_{i=1}^{6} w_{i} \cdot\left(\frac{B}{H}\right)^{p_{i 1}} \cdot\left(\frac{B}{2 t_{f}}\right)^{p_{i 2}} \cdot\left(\frac{H}{t_{w}}\right)^{p_{i 3}} \cdot\left(\frac{L}{H}\right)^{p_{i 4}}\right) \\
& \gamma_{\max }=\sum_{i=1}^{6} w_{i} \cdot\left(\frac{B}{H}\right)^{p_{i 1}} \cdot\left(\frac{B}{2 t_{f}}\right)^{p_{i 2}} \cdot\left(\frac{H}{t_{w}}\right)^{p_{i 3}} \cdot\left(\frac{L}{H}\right)^{p_{i 4}}
\end{aligned}
$$

せん断力である $Q_{y}, Q_{\max }, Q_{0.05 r a d}$ の算定式については, 端部が全 塑性モーメント $M_{p}$ に達するときのせん断力である $Q_{p}$ を基準として, そこからの増減比率を, 形状変数 $H, B, t_{w}, t_{f}, L$ から定まる 4 つ の無次元量である幅せい比 $B / H$, フランジ幅厚比 $B / 2 t_{f}$, ウェブ幅厚 比 $H / t_{w}$, アスペクト比 $L / H$ のべき乗の積で構成される項の級数で表 す形式としている。このように $Q_{p}$ の值を基本とした式の形にしたの は, FA ランクの梁であれば, $Q_{p}$ によって降伏荷重等の值は一定の 精度で推定可能と考えたためである。 $Q_{p}$ は以下の式を用いて寸法值 および材料の降伏応力度 $\sigma_{y}$ から算定できる。

$$
Q_{p}=M_{p} / L=\sigma_{y} \cdot\left\{H \cdot B \cdot t_{f}+\frac{H^{2} \cdot t_{w}}{4}\right\} / L
$$

無次元量である変形角 $\gamma_{\max }$ については, $Q_{p}$ のような基本量は設け ず 4 つの無次元量のべき乗の積で構成される項の級数によって直接 的に表す形式としている。なお, 式中にも記したように, 級数の項 数についてはいずれの算定式も 6 としている。したがって, 同定す
Table 1 Material property of steel used for analysis

\begin{tabular}{c|c|c}
\hline $\begin{array}{c}E \\
(\mathrm{GPa})\end{array}$ & $v$ & $\begin{array}{c}\sigma_{y} \\
(\mathrm{MPa})\end{array}$ \\
\hline 205 & 0.3 & 325 \\
\hline
\end{tabular}

Table 2 Size parameter for training data

\begin{tabular}{c|c}
\hline$H(\mathrm{~mm})$ & $400,500,600,700,800$ \\
\hline$B(\mathrm{~mm})$ & 200,300 \\
\hline$t_{w}(\mathrm{~mm})$ & $12,16,20,24$ \\
\hline$t_{f}(\mathrm{~mm})$ & $16,20,24$ \\
\hline$L(\mathrm{~mm})$ & $2000,3000,4000,5000,6000,7000,8000$ \\
\hline & $*$ Excludes cases where $B / 2 t_{f}>8.08$ or $H / t_{w}>36.6$
\end{tabular}

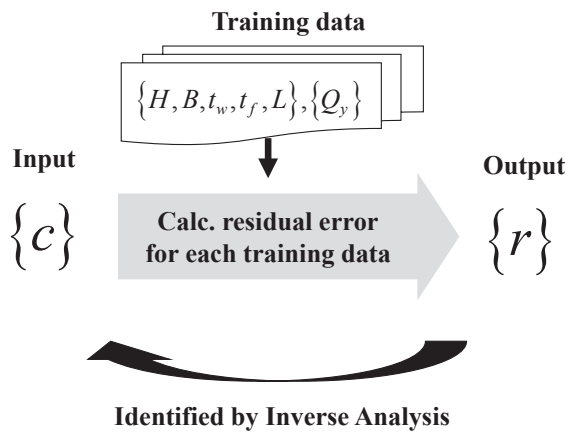

Fig. 5 Inverse problem

る未知の係数は 6 つの重み係数 $w_{i}$ を加えた 30 個となる。なお，こ の式表現は, 唯一性が担保される直交する基底関数の線形結合のよ うな構成にはなっていないため, 同じ算定結果となる未知係数の組 が複数存在する。

Fig.5 には，与えられた教師データからこれらの未知係数を同定す るときに想定する逆問題のイメージを， $Q_{y}$ の例を用いて示す。図に 示寸ように, 未知係数をまとめた未知係数ベクトル\{c\}が定まれば算 定式が決定されるため, それぞれの教師データに対する誤差は容易 に計算できる。この誤差をまとめた誤差べクトル $\{r\}$ を未知係数ベク トルから計算する処理を順解析とみなし, 誤差べクトルを零にする ような未知係数ベクトル $\{c\}$ を, 以降で説明する逆解析手法で探索す る。これにより，未知係数ベクトルが同定された(3)〜(6)式の近似関 数が陽な形で得られる。

\section{5 算定式導出に用いる関数同定手法}

本節では，算定式の未知係数の同定に用いる文献 4 の関数同定手 法について説明する。

文献 4 の手法の特徵は「誤差を減少させる修正」と「不要な成分 を削除する修正」の 2 つ処理を実施する点にある。これにより， 教師データの再現精度を確保しつつ, (3)〜 (6)式のような同じ算定結 果となる未知係数の組が複数存在する場合であっても, 本質的な項 のみで構成される関数の同定が可能となる。具体的には, 前者の処 理には, 文献 6 に示されたモーダル反復誤差修正法を用いる。モー ダル反復誤差修正法は, 誤差ベクトルの入力ベクトルの各成分に対 する偏微分で構成されるヤコビアンマトリクスの特異值分解から有 
意なモードを選択し, 反復的に誤差を修正する手法である。ヤコビ アンマトリクスの逆行列を特異值の大きな主要なモードのみで構成 することで, 効率的な誤差の縮小が可能であり, 収斂性能を向上さ せることができる。また, 後者の処理には, 文献 7 のノイズ除去手 法を用いる。この手法は, 上記ヤコビアンマトリクスの特異值分解 によって得られるモードのうち, 特異值の小さなモードに着目して, 入力ベクトルに含まれる不要な成分を削除する方法である。この 2 つの処理を実施することにより, 教師データの再現精度を確保しつ つ, 本質的な項のみで構成される関数の同定が可能となる。このよ うな不要な成分を削除した数式同定は最小二乗法などの誤差の減少 のみを目的とした探索手法では実施困難である。詳細な計算手順に ついては文献 4 を確認されたい。

推定された算定式 $f$ の誤差は, 下式によって計算される各教師デ 一タに対する誤差率 $r_{k}$ で構成される誤差ベクトル $\{r\}$ で評価する。こ こで, 添え字 $k$ は $k$ 番目の教師データの值であることを示し, $\delta_{k}$, $\left\{x_{k}\right\}$ がそれぞれ $k$ 番目の教師データの出力值および入力ベクトルに 対応する。なお, 解析結果が持つ計算誤差にばらつきによる過学習 を防ぎより単純な数式を得られるようにするために, 文献 4 と同様 に, 予め設定した許容誤差率 $\alpha$ の範囲内では誤差がないものとみな す。本検討において， $\alpha$ は 0.1 とする。

$$
r_{k}=\left\{\begin{array}{cc}
\frac{\delta_{k}-f\left(\left\{x_{k}\right\}\right)}{\delta_{k}} & \left(\text { where }\left|\left\{\delta_{k}-f\left(\left\{x_{k}\right\}\right)\right\} / \delta_{k}\right|>\alpha\right) \\
0 & (\text { else })
\end{array}\right.
$$

探索開始時に用いる未知係数ベクトルは Table 3 に示す值を用い る。初期值は 1 を基本として, 重解が算出されることを避けるよう に 1〜 5 項にはひとつの指数を 2 とした值を用いている。

誤差を減らすために主要なモードを選別する際のモード選別手法 は, Fig. 6 に示す「誤差ベクトルのノルム比」によって設定する ${ }^{8)}$ 。 横軸は用いるモードの数 $N$, 縦軸は $N$ 次までのモードで表現できる 誤差ベクトル\{r'\}のノルムである。まず, 特異值が十分小さいと判 断されるモードを除いた $n_{\text {main }}$ 個のモードを用いた場合の誤差べクト ル $\left\{r^{\prime}{ }_{\text {main }}\right\}$ のノルムを算出し，このノルムに対する比が予め定めた閾 值 $\eta_{\text {limit }}$ に達した時点のモード数を修正に用いるモード数 $n_{\text {select }}$ とす る。なお，全モードを用いた場合の䛊差を基準としなかったのは， 特異值の微小なモードが含まれ, 発散に至る事象を回避するためで ある。

誤差ベクトルのノルム比は以下の式によって表される。なお，こ こで特異值が十分小さなモードとは, 第 1 特異值の $10^{-5}$ 倍未満の特 異値となるモードとする。

$$
\frac{\left|\left\{r_{\text {select }}^{\prime}\right\}\right|}{\left|\left\{r_{\text {main }}^{\prime}\right\}\right|}=\sqrt{\sum_{i=1}^{n_{\text {select }}}\left(\left\{\mathrm{u}_{i}\right\}^{\mathrm{T}}\{r\}\right)^{2} / \sum_{i=1}^{n_{\text {main }}}\left(\left\{\mathrm{u}_{i}\right\}^{\mathrm{T}}\{r\}\right)^{2}}
$$

ここで $\left\{\mathrm{u}_{i}\right\}$ は出力側のモードマトリクス $[\mathrm{U}]$ の $i$ 列の成分である。 これにより, 誤差ベクトルが主として低次のモードだけで構成され る時には低次のモードのみを用いて修正を行い, 高次のモードが含 まれるときには高次のモードを含めて修正を行うことができる。 $\eta_{\text {limit }}$ の適切な值は適用する問題によって変化すると考えられるため, 試行錯誤の方法によって定めるべき值であるが，本研究では文献 4 と同じく 0.2 とした。

不要な入力成分を除去する処理において縮退するモードを選択す
Table 3 Initial coefficients

\begin{tabular}{c|c|c|c|c|c}
\hline$i$ & $\mathrm{w}_{i}$ & $\mathrm{p}_{i 1}$ & $\mathrm{p}_{i 2}$ & $\mathrm{p}_{i 3}$ & $\mathrm{p}_{i 4}$ \\
\hline 1 & 2 & 1 & 1 & 1 & 1 \\
\hline 2 & 1 & 2 & 1 & 1 & 1 \\
\hline 3 & 1 & 1 & 2 & 1 & 1 \\
\hline 4 & 1 & 1 & 1 & 2 & 1 \\
\hline 5 & 1 & 1 & 1 & 1 & 2 \\
\hline 6 & 1 & 1 & 1 & 1 & 1 \\
\hline
\end{tabular}

Norm of residual vector consisted with selected modes

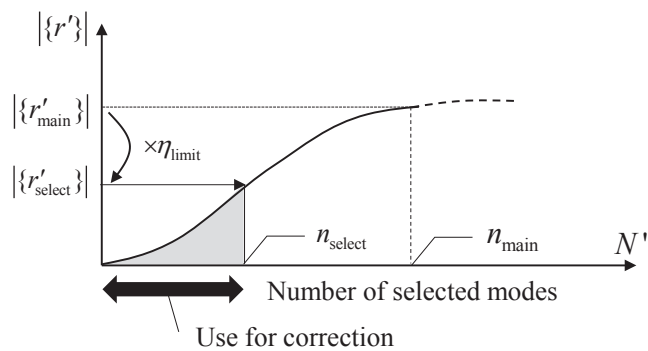

Fig. 6 Main mode selection method

る際に特異値が十分小さいと判断する特異值の閾值は, 誤差削減時 と同じく，第 1 特異值の $10^{-5}$ 倍未満とし，モードの削減率入は 0.10 とする。ヤコビアンマトリクスを計算する際の微分には数值微分を 用い, 摂動量は 0.0001 とし, 反復回数は 500 回で打ち切りとする。

\section{3. 算定式の同定結果}

\section{1 教師データに対する精度}

本節では，2 章で説明した条件を用いて同定された 4 つの算定式 の教師データに対する精度を確認する。

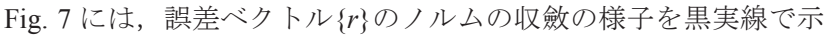
す。図中丸印は最も誤差が小さくなった点である。図より，いずれ の同定式においても初期にあった誤差は, 100 回程度の収斂計算で 1.0 程度まで低下し, その後は停留している。それぞれの誤差の最 小值は, $Q_{y}$ で $0.65, Q_{\max }$ で $0.33, \gamma_{\max }$ で $3.75, Q_{0.05 \mathrm{rad}}$ で 3.03 となり, やや $\gamma_{\max }, Q_{0.05 \mathrm{rad}}$ の誤差が大きくなる結果となった。

Fig. 8 には, 同定された係数べクトル $\{c\}$ のルム (二乗和平方根) の収斂の様子を 6 項それぞれに分けて黒実線で示す。図より，いず れの算定式においても初期においては, Fig.7 に示した誤差の収斂と ともに全ての項のノルムは徐々に減少していることがわかる。その 後, ノルムが増加に転じる項と減少を続ける項に分かれている。後 者は, 最終的にはノルムが 0 まで減少しており, 不要と判断された 項であると考えられる。最終的に残った項数は， $Q_{y}, Q_{\max }, Q_{0.05 \mathrm{rad}}$ が 1 項, $\gamma_{\max }$ は 3 項となり, $\gamma_{\max }$ 以外は項数の少ない式が探索されて いる。これは一般的な誤差修正法にはない「不要な成分を削除する 修正」処理が有効に機能していることを示していると考えられる。

Table 4 には，それぞれの解析ケースにおける収斂計算終了時に同 定された係数群の一覧を示す。なお，小数第 3 位までの記載として いる。前述したように, $Q_{y}, Q_{\max }, Q_{0.05 \mathrm{rad}}$ は 1 項のみの比較的単純 な式が同定されているが, $\gamma_{\max }$ は 3 項の複雑な式が同定されている。 最大荷重時の変形角は, 単純な式では表現しきれない出力であると 考えられる。 


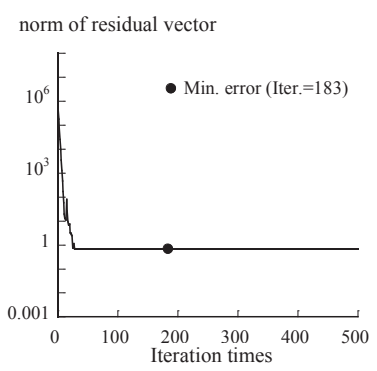

(a) $Q_{y}$

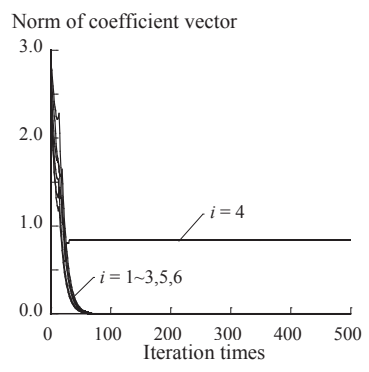

(a) $Q_{y}$

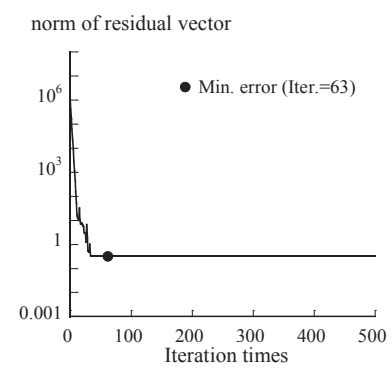

(b) $Q_{\max }$

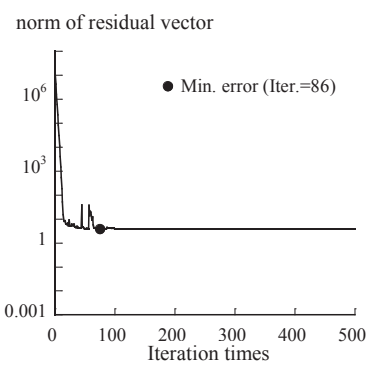

(c) $\gamma_{\max }$

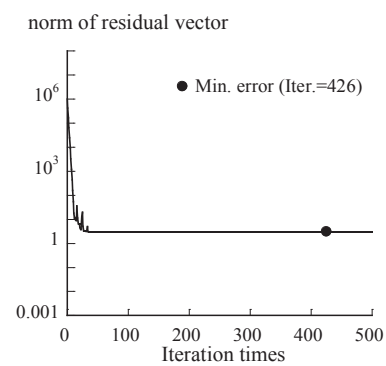

(d) $Q_{0.05 \mathrm{rad}}$

Fig. 7 RSS error

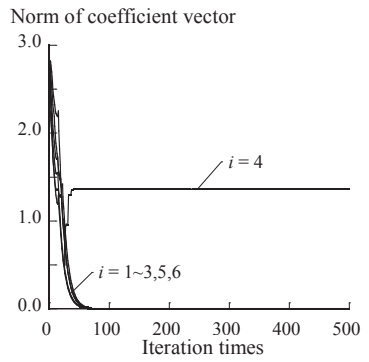

(b) $Q_{\max }$

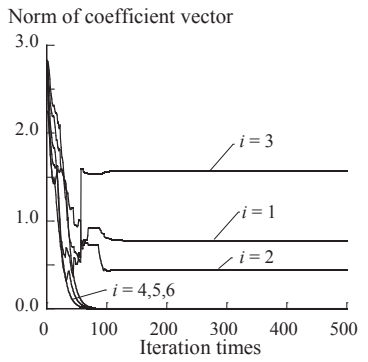

(c) $\gamma_{\max }$

Fig. 8 Norm of coefficient vector

\section{Table 4 Identified Coefficient}

(a) $Q_{y}$ \begin{tabular}{c|c|c|c|c|c}
\hline$i$ & $\mathrm{~W}_{i}$ & $\mathrm{p}_{i 1}$ & $\mathrm{p}_{i 2}$ & $\mathrm{p}_{i 3}$ & $\mathrm{p}_{i 4}$ \\
\hline 1 & 0.000 & 0.000 & 0.000 & 0.000 & 0.000 \\
\hline 2 & 0.000 & 0.000 & 0.000 & 0.000 & 0.000 \\
\hline 3 & 0.000 & 0.000 & 0.000 & 0.000 & 0.000 \\
\hline 4 & 0.836 & 0.008 & 0.002 & 0.035 & 0.000 \\
\hline 5 & 0.000 & 0.000 & 0.000 & 0.000 & 0.000 \\
\hline 6 & 0.000 & 0.000 & 0.000 & 0.000 & 0.000
\end{tabular}

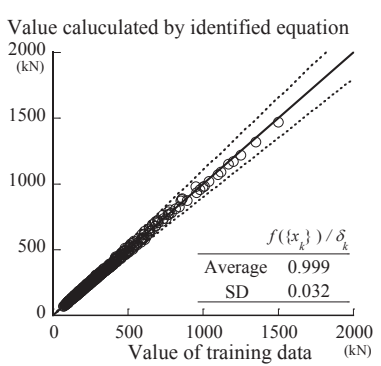

(a) $Q_{y}$ (b) $Q_{\max }$

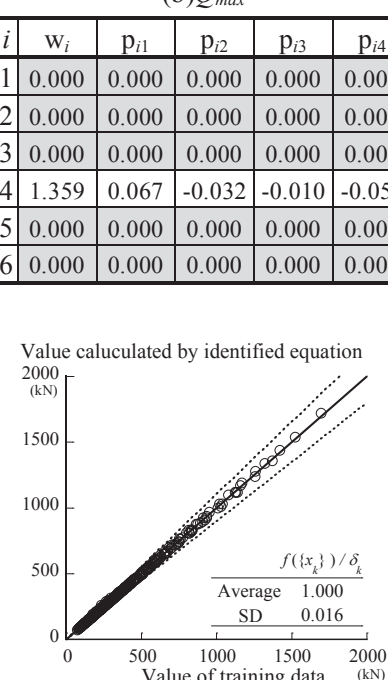

(b) $Q_{\max }$ (c) $\gamma_{\max }$

\begin{tabular}{c|c|c|c|c|c}
\hline$i$ & $\mathrm{w}_{i}$ & $\mathrm{p}_{i 1}$ & $\mathrm{p}_{i 2}$ & $\mathrm{p}_{i 3}$ & $\mathrm{p}_{i 4}$ \\
\hline 1 & 0.268 & 0.708 & -0.139 & -0.125 & 0.001 \\
\hline
\end{tabular}
\begin{tabular}{l|c|c|c|c|c}
\hline 1 & 0.000 & 0.000 & 0.000 & 0.000 & 0.000 \\
\hline
\end{tabular}

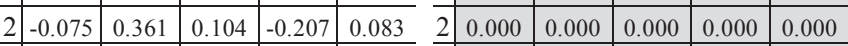
\begin{tabular}{l|l|l|l|l|l|ll|l|l|l|l|l|}
3 & 0.000 & 0.019 & 0.445 & 1.239 & 0.860 & 3 & 0.000 & 0.000 & 0.000 & 0.000 & 0.000 \\
\hline
\end{tabular} \begin{tabular}{|l|l|l|l|l|l|ll|l|l|l|l|l|}
\hline 4 & 0.000 & 0.000 & 0.000 & 0.000 & 0.000 & & 4 & 4.111 & 0.547 & -0.217 & -0.075 & -0.188 \\
\hline
\end{tabular} \begin{tabular}{l|l|l|l|l|l}
\hline 5 & 0.000 & 0.000 & 0.000 & 0.000 & 0.000 \\
\hline 6 & 0.000 & 0.000 & 0.000 & 0.000 & 0.000 \\
\hline
\end{tabular} \begin{tabular}{llllllll}
5 & 0.000 & 0.000 & 0.000 & 0.000 & 0.000 \\
\hline
\end{tabular} \begin{tabular}{l|l|l|l|l|l|l|l|l|l|l|l}
\hline 6 & 0.000 & 0.000 & 0.000 & 0.000 & 0.000 & & 0.000 & 0.000 & 0.000 & 0.000 & 0.000 \\
\hline
\end{tabular}

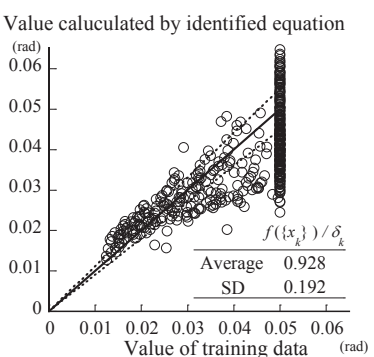

(c) $\gamma_{\max }$

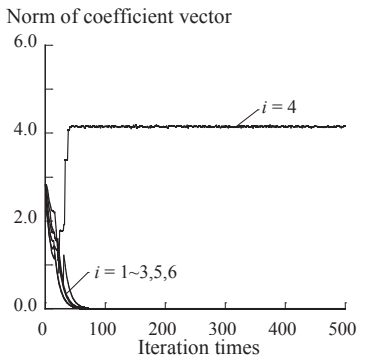

(d) $Q_{0.05 \mathrm{rad}}$

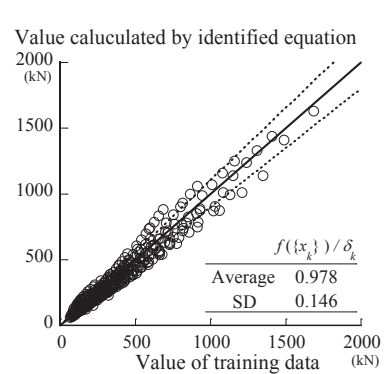

(d) $Q_{0.05 \mathrm{rad}}$

Fig.9 Accuracy of Identified equation for training data

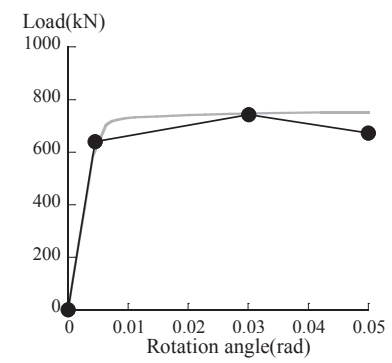

(a)H600x200x20x20, L=2000

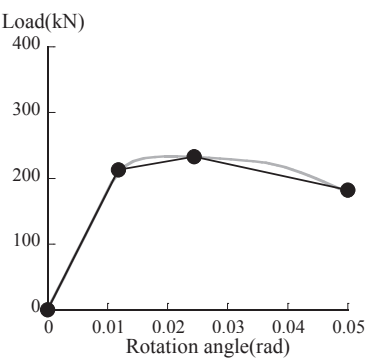

(b) $H 600 \times 200 \times 20 \times 20, L=6000$

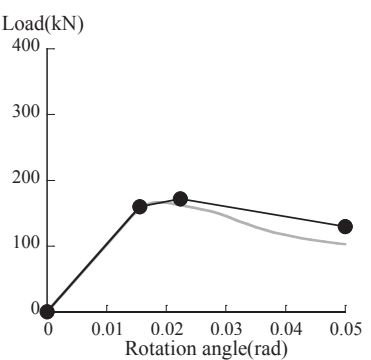

(c) $\mathrm{H} 600 \times 200 \times 20 \times 20, \mathrm{~L}=8000$

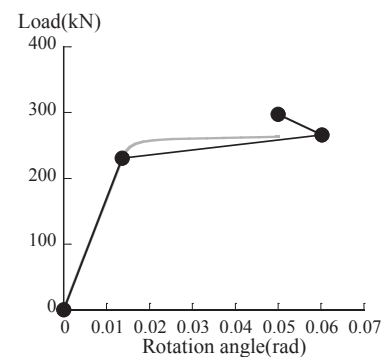

(d) $\mathrm{H} 400 \times 300 \times 24 \times 24, \mathrm{~L}=5000$

Fig.10 Skelton curve calculated by identified equation for training data 
Fig.9 には, Table 4 に示した係数群で構成される(3) (6)式の算定式 の精度を示す。横軸が教師データの各特性值 $\left(\delta_{k}\right)$ を, 縦軸がそれ ぞれの教師データの寸法に対して同定された算定式を用いて算定さ れた各特性值 $\left(f\left(\left\{x_{k}\right\}\right)\right)$ を示している。図中に示した傾き 1 の黒実 線は, 誤差がない場合に対応し, 図中黒破線が誤差 $\pm 10 \%$ に対応す る。また, $f\left(\left\{x_{k}\right\}\right) / \delta_{k}$ の平均值および標準偏差も図中に併せて示す。 図より, $Q_{y}, Q_{\max }$ の再現精度は良好であり, 平均誤差は $1 \%$ 未満, 標準偏差 3\%程度に収まっていることがわかる。また， $Q_{0.05 \mathrm{rad}}$ は部分 的に誤差土10\%を超過している個所があり, ばらつきも $15 \%$ 程度と やや大きいが，平均誤差は 3\%程度に収まっている。一方， $\gamma_{\text {max }}$ にお いては, 平均誤差が $7 \%$ 程度, 標準偏差が $20 \%$ 程度と大きな值とな っており，傾向も捉えているとは言い難い精度となっている。この 平均誤差の大小関係は, Fig.7の結果と整合している。

$\gamma_{\text {max }}$ の精度が大きく低下したのは, 今回の解析は $0.05 \mathrm{rad}$ の変形ま でしか実施しないため, 仮に 0.05 rad まで耐力劣化が生じない場合 には， $\gamma_{\max }$ が一律 $0.05 \mathrm{rad}$ となってしまうことが原因と考えられる。 Fig.10 には, Table4 で示した係数に対応寸る数式を用いて算定さ れた骨格曲線と解析から得られた荷重変位関係の比較を示す。(a)〜 (c)は，代表断面として選定した H600x200x20x20 の断面の梁長さ $\mathrm{L}=2000 ， 6000 ， 8000 \mathrm{~mm}$ の荷重変位関係の比較である。プロットお よび黒実線が算定された骨格曲線を, 灰実線が数值解析結果に対応 する。図より, 世ん断が支配的な短い梁, 曲げが支配的な長い梁の いずれにおいても, やや耐力劣化域の精度は低下寸るものの全体と して荷重変位関係の傾向を表現する骨格曲線が算定できていること がわかる。その他の断面についても概ね良好な精度で表現できるこ とを確認しているが， $\gamma_{\max }$ については大きな誤差が発生し，その結 果として算定される骨格曲線が大きく異なってしまう場合があった。

そこで，(d)には， $\gamma_{\max }$ の誤差により算定されるスケルトンカーブに 大きな影響を与えてしまう事例として, H400x300x24×24, L=5000mm の結果を示す。図に示すように，このケースにおいては， $\gamma_{\max }$ を 0.05 よりも大きく推定してしまうことにより, 骨格曲線が大きく崩れて いる。このようなケースは, フランジ幅厚比やウェブ幅厚比が小さ な FA ランクの中でも小さく, 耐力劣化が生じにくい断面において 多く生じていた。

以上のように, Fig.3 に示した特性值によって骨格曲線を定義する 方法では, 変形角 $0.05 \mathrm{rad}$ まで耐力劣化が生じないケースが含まれ ることがあるために, 特に $\gamma_{\max }$ の精度の低下, それによる骨格曲線 への悪影響が生じることが確認できた。この対応については, 3.3 節にて対応方法を考察, 検討する。

\section{2 検証データに対する精度}

つづいて，本節においては数式の同定の際に教師データとして用 いていない Table5 に示した寸法の結果を検証用データとして, 同定 された算定式の妥当性, 汎化性能を確認寸る。検証データの数は 144 である。

Fig.11 には, Table 4 に示した係数群で構成される算定式の検証デ 一夕の精度を示す。Fig.9 と同様に, 横軸が検証データの各特性值 $\left(\delta_{k}\right)$

Table 5 Size parameter for validation data

\begin{tabular}{c|c}
\hline$H(\mathrm{~mm})$ & $450,550,650,750$ \\
\hline$B(\mathrm{~mm})$ & 250,350 \\
\hline$t_{w}(\mathrm{~mm})$ & $14,18,22$ \\
\hline$t_{f}(\mathrm{~mm})$ & 18,22 \\
\hline$L(\mathrm{~mm})$ & $2500,3500,4500,5500,6500,7500$ \\
\hline & $*$ Excludes cases where $\mathrm{B} / 2 \mathrm{t}_{\mathrm{f}}>8.08$ or $\mathrm{H} / \mathrm{t}_{\mathrm{w}}>36$
\end{tabular}

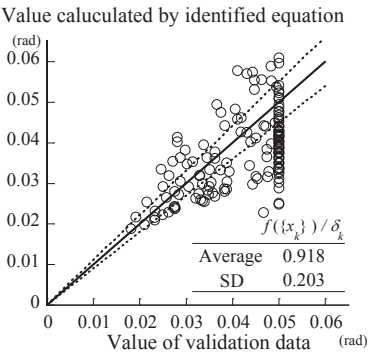

(c) $\gamma_{\max }$

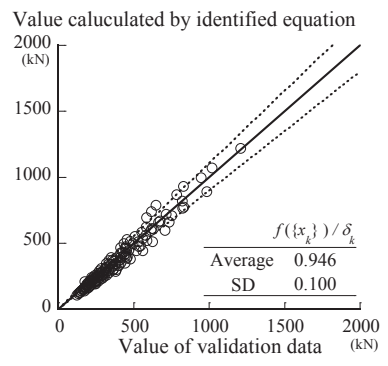

(d) $Q_{0.05 r a d}$

Fig.11 Accuracy of Identified equation for validation data

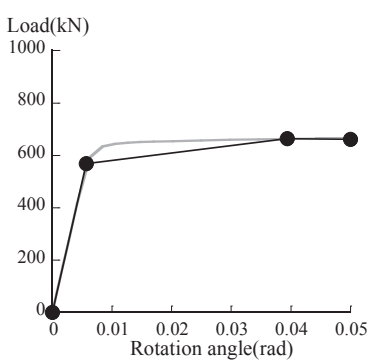

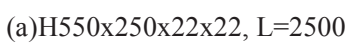

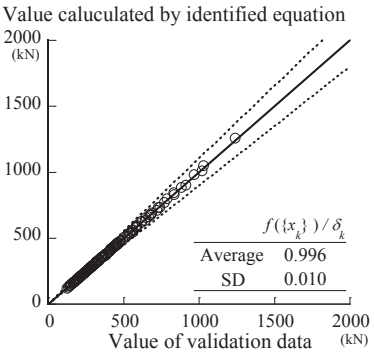

(b) $Q_{\max }$

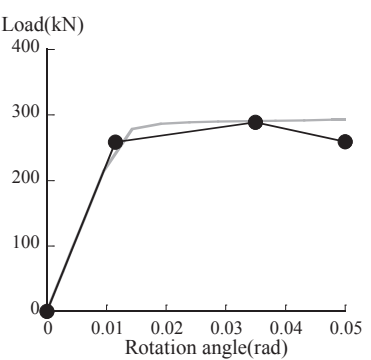

(b) $\mathrm{H} 550 \times 250 \times 22 \times 22, \mathrm{~L}=5500$

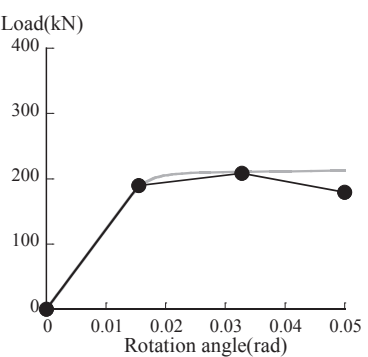

(c) $\mathrm{H} 550 \times 250 \times 22 \times 22, \mathrm{~L}=7500$

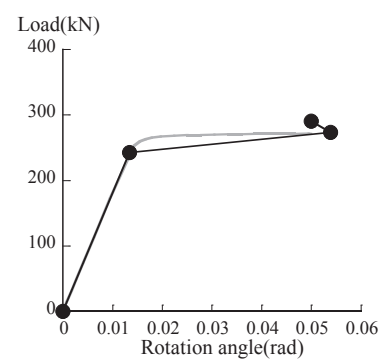

(d) $\mathrm{H} 450 \times 350 \times 18 \times 22, \mathrm{~L}=5500$

Fig.12 Skelton curve calculated by identified equation for validation data 
を, 縦軸がそれぞれの検証データの寸法に対して同定された算定式 を用いて算定された各特性值 $\left(f\left(\left\{x_{k}\right\}\right)\right)$ を示している。誤差 0 およ び土 $10 \%$ の直線および $f\left(\left\{x_{k}\right\}\right) / \delta_{k}$ の平均值および標準偏差も同様に併 せて示す。図より，全体的な傾向は教師データ同様であることがわ かる。 $Q_{y}, Q_{\max }$ の再現精度は良好であり, 平均誤差 $1 \%$ 以内に収ま っており, 標準偏差も $3 \%$ 程度に収まっている。Q $Q_{0.05 r a d}$ は部分的に誤 差土10\%を超過している個所があり, ばらつきも $10 \%$ 程度とやや大 きいが，平均誤差は $5 \%$ 程度に収まっている。 $\gamma_{\max }$ は依然誤差も大き く, 傾向も捉えているとは言い難い精度となっており，0.05 rad を越 える值も算定されていることがわかる。

Fig.12には, 検証データに対して Table4 で示した係数に対応する 数式を用いて算定された骨格曲線と解析から得られた荷重変位関係 の比較を示す。(a)〜 (c)は, 代表断面として選定した H550x250x22×22 の断面の梁長さ $\mathrm{L}=2500,5500,7500 \mathrm{~mm}$ の荷重変位関係の比較であ る。プロットおよび黒実線が算定された骨格曲線を, 灰実線が数值 解析結果に対応する。図より, 検証データにおいても, せん断が支 配的な短い梁, 曲げが支配的な長い梁のいずれにおいても, 全体と して荷重変位関係の傾向を表現する骨格曲線が算定できていること がわかる。ただし，(d)に示すように， $\gamma_{\max }$ を 0.05 よりも大きく推定 してしまうことにより, 骨格曲線が大きく崩れてしまうケースも存 在した。

以上のように, 同定された算定式の検証データに対する精度は, 教師データに対する精度と比較して大きく低下寸ることはなく過学 習は生じておらず, 一定の汎化性能が確保されていることが確認で きた。

\section{$3.3 Q_{0.03 r a d}$ を用いた骨格曲線の構築}

前節までに, 骨格曲線の特性值として最大耐力点を用いる場合, 最大耐力時の変形角 $\gamma_{\text {max }}$ の精度が低下し, 骨格曲線の導出が不適切 になる場合があることが確認された。これは, 最大耐力時の変形が 単純な数式では捉えにくい上, 最大耐力点が $0.05 \mathrm{rad}$ を越えてしま うケースが存在してしまうことの影響が大きい。そこで, 本節では, Fig.13 に示すように骨格曲線の第 2 折れ点を, 「変形角 $0.03 \mathrm{rad}$ 時の 点」として定義し, その荷重值 $Q_{0.03 \mathrm{rad}}$ の算定式を導出することを考 える。前節で同定した $Q_{0.05 \mathrm{rad}}$ に類似した定義の方法であることから 一定の精度は見込める上, この対応により最大耐力点が $0.05 \mathrm{rad}$ を 越えてしまうケースにも対応可能となる。

$Q_{0.03 \mathrm{rad}}$ の数式は, $Q_{0.05 \mathrm{rad}}$ と同様に, 以下のように設定し, 前節ま でと同様の方法を用いて式中の未知数を同定する。

$$
Q_{0.03 \mathrm{rad}}=Q_{p} \cdot\left(\sum_{i=1}^{6} w_{i} \cdot\left(\frac{B}{H}\right)^{p_{i 1}} \cdot\left(\frac{B}{2 t_{f}}\right)^{p_{i 2}} \cdot\left(\frac{H}{t_{w}}\right)^{p_{i 3}} \cdot\left(\frac{L}{H}\right)^{p_{i 4}}\right)
$$

Table6 には, 教師データから同定された係数ベクトルの一覧を示 す。表より，前節の $Q_{y}, Q_{\max }, Q_{0.05 r a d}$ 同様, 1 項のみの単純な式が同 定されていることがわかる。

また, Fig.14には, Table 6 に示した係数群で構成される算定式の 教師データおよび検証データに対する精度を示す。横軸が教師デー タおよび検証データの各特性值を, 縦軸が同定された算定式を用い て算定された各特性值を示している。その他の記載值は Fig.9, Fig.11 と同様である。図より, 教師データ, 検証データの両者に対して, 平均誤差は $5 \%$ 程度, 標準偏差は $10 \%$ 程度に収まっており, 前節の

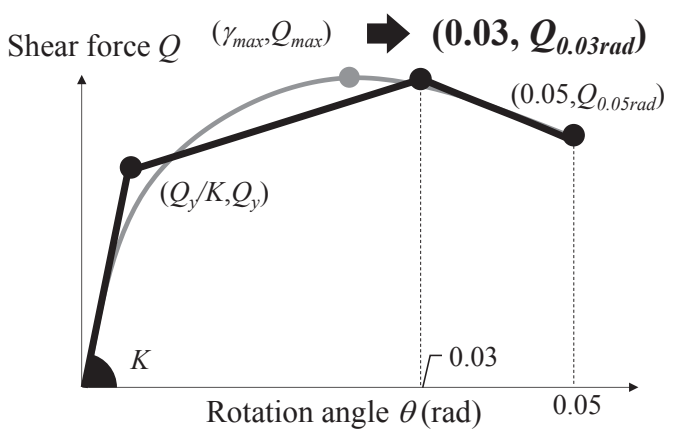

Fig. 13 Renew Tri-linear curve definition

Table 6 Identified Coefficient for $Q_{0.03 r a d}$

\begin{tabular}{c|c|c|c|c|c}
\hline $\mathrm{i}$ & $\mathrm{w}_{\mathrm{i}}$ & $\mathrm{p}_{\mathrm{i} 1}$ & $\mathrm{p}_{\mathrm{i} 2}$ & $\mathrm{p}_{\mathrm{i} 3}$ & $\mathrm{p}_{\mathrm{i} 4}$ \\
\hline 1 & 0.000 & 0.000 & 0.000 & 0.000 & 0.000 \\
\hline 2 & 0.000 & 0.000 & 0.000 & 0.000 & 0.000 \\
\hline 3 & 0.000 & 0.000 & 0.000 & 0.000 & 0.000 \\
\hline 4 & 2.543 & 0.328 & -0.145 & -0.043 & -0.129 \\
\hline 5 & 0.000 & 0.000 & 0.000 & 0.000 & 0.000 \\
\hline 6 & 0.000 & 0.000 & 0.000 & 0.000 & 0.000 \\
\hline
\end{tabular}

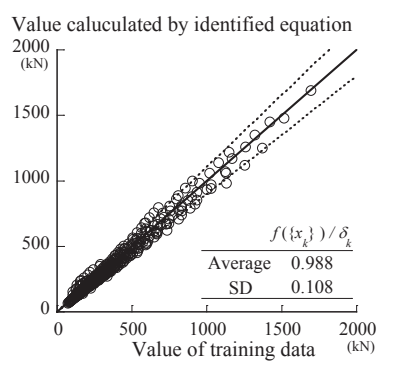

(a)training data

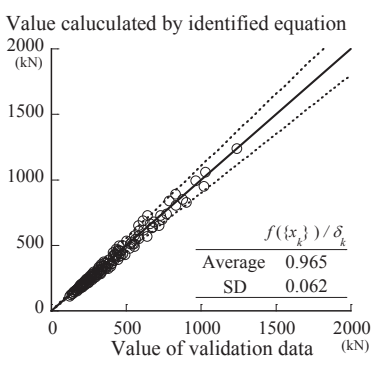

(b)validation data
Fig. 14 Accuracy of Identified equation for $Q_{0.03 r a d}$

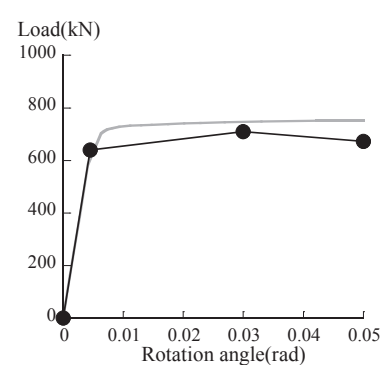

(a) $\mathrm{H} 600 \times 200 \times 20 \times 20, \mathrm{~L}=2000$

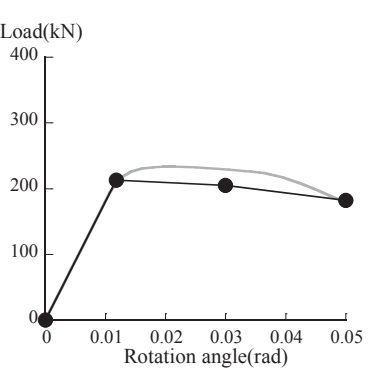

(b) $\mathrm{H} 600 \times 200 \times 20 \times 20, \mathrm{~L}=6000$

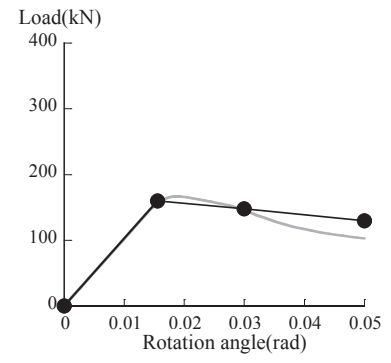

(c) $\mathrm{H} 600 \times 200 \times 20 \times 20, \mathrm{~L}=8000$

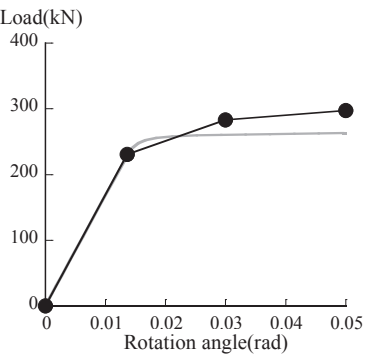

(d) $\mathrm{H} 400 \times 300 \times 24 \times 24, \mathrm{~L}=5000$
Fig. 15 Skelton curve using calculated $Q_{0.03 \mathrm{rad}}$ 
$\gamma_{\max }$ と比較して良好に対応している。Fig.15には, Fig.10に示したケ 一スに対して, 第 2 折れ点を「変形角 $0.03 \mathrm{rad}$ 時の点」とし, $Q_{0.03 \mathrm{rad}}$ を用いて算定して得られる骨格曲線を示す。最大耐力は変形角を $0.03 \mathrm{rad}$ に固定しているため, 最大耐力点を捉えることは出来ていな いものの数值解析結果から得られる荷重変位関係を概社模擬できて いることがわかる。また, 従来は第 2 折れ点の誤差のために骨格曲 線が反転してしまう(d)のケースも, 今回の方法であれば反転を生じ ずに骨格曲線の算定ができていることがわかる。

以上のように, 最大耐力点ではなく, 予め設定した変形角におけ る荷重值を骨格曲線の特性值とすることで骨格曲線の算定精度を安 定させることが可能であることが確認できた。さらに, 他の変形角 における荷重值の算定式も作成し, 骨格曲線の折れ点を増やすこと で，より精度を向上させることも可能であると考えられる。

\section{4. まとめ}

本研究においては, 文献 4 の手法を用いて, 事前に実施した数值 解析の入出力システムを単純な数式の形で表現できるかどうかを, 鋼梁の骨格曲線算定式の導出を例題として検証を行った。まず, 関 数同定手法の概要を説明するとともに, 例題とする関数同定問題に ついて説明した。つづいて, 関数同定結果を示し, 同定手法の適用 性を検証した。得られた知見を以下に示す。

1) 数值解析結果を教師データとして, 鋼梁の骨格曲線の諸元となる 特性值の算定式を導出した。導出する特性值は, 降伏荷重 $Q_{y}$, 最 大荷重 $Q_{\max }$, 最大荷重時の変形角 $\gamma_{\text {max }}$ および変形角 $1 / 20 \mathrm{rad}$ 時の荷 重 $Q_{0.05 r a d}$, の 4 種とし, 変数とする入力パラメータは形状データ とし, 幅せい比 $B / H$, フランジ幅厚比 $B / 2 t_{f}$, ウェブ幅厚比 $H / t_{w}$, アスペクト比 $L / H$ の 4 種として, 文献 4 に示された手法を用いて 算定式の導出を行った。その結果， $Q_{y}, Q_{\max }, Q_{0.05 \mathrm{rad}}$ においては 1 項のみで, $\gamma_{\max }$ においては 3 項で, 構成される数式が導出された。

2) 同定された算定式の教師データに対する再現精度を確認した。そ の結果, 降伏荷重 $Q_{y}$, 最大荷重 $Q_{\max }$, 変形角 $1 / 20 \mathrm{rad}$ 時の荷重 $Q_{0.05 \mathrm{rad}}$ の精度は概ね確保されたが, 最大荷重時の変形角 $\gamma_{\text {max }}$ については 精度が大きく低下寸る傾向となった。これは, 最大荷重時の変形 角の推定に複雑な数式が必要になることのほか, 変形角 $0.05 \mathrm{rad}$ まで耐力劣化が生じないケースが含まれてしまうためであると考 えられる。また, 検証データに対する再現精度は教師データとほ ぼ同等であり，過学習は生じていなかった。

3)精度向上および骨格曲線の反転を防ぐことを目的に, 最大荷重点 の代わりに,「変形角 $0.03 \mathrm{rad}$ 時」を第 2 折れ点とする方法の適用 性を検証した。その結果, 「変形角 $0.03 \mathrm{rad}$ 時」の荷重 $Q_{0.03 \mathrm{rad}}$ の算 定式の精度は比較的良好であり, 最大耐力点を捉えることはでき ないものの, 骨格曲線の反転事象は生じないことが確認された。

以上のように, 文献 4 の手法により, 事前に実施した数值解析の 入出力システムを単純な数式の形で表現できることが確認できた。 今回は一例として鋼梁の骨格曲線算定式の事例を示したが, 柱の骨 格曲線算定式も構築することで, 部材寸法に応じたフレーム解析用 の入力值算定が可能になる。また, 本手法は構造解析に留まらない 様々な数值解析に対しても, その解析結果を略算寸るための算定式
の導出に適用可能であると考えている。

\section{付録 不要な成分を削除する修正処理の効果}

ここでは, 本研究で用いた数式同定手法の特徽である,「不要な成 分を削除する修正処理」の効果を確認する。この処理により, Table4 等に示される不要な未知係数を 0 とする同定が可能になっているこ とを示すために，当該処理を実施せずに，最小二乗法等の一般的な 同定手法と同様に「誤差を減少させる修正」のみで $Q_{y}$ の算定式の同 定を実施した場合の結果を，Fig.A1 および Table A1 に示す。

図より，精度については Fig.9(a)とほぼ同等であることがわかる。 一方, 同定された未知係数は Table 4(a) とは異なり, 全ての未知係数 に何らかの数值が入っており, 単純な数式での表現となっていない。 したがって, 単純化された数式の導出には「不要な成分を削除する 修正処理」が必要といえる。そのため, 最小二乗法等を含む一般的 な同定手法においても, 今回用いた同定手法と同程度まで誤差を縮 小できる可能性はあるが, 不要な未知係数を 0 とする同定は困難で あると考えられる。

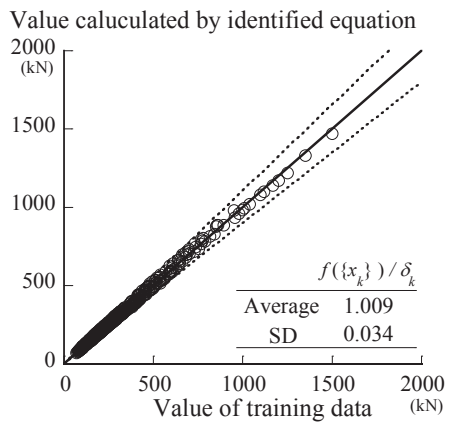

Fig.A1 Accuracy of Identified equation for training data (Qy, without reduction process)

Table A1 Identified Coefficient for $Q_{y}$ without reduction process

\begin{tabular}{c|c|c|c|c|c}
\hline $\mathrm{i}$ & $\mathrm{w}_{\mathrm{i}}$ & $\mathrm{p}_{\mathrm{i} 1}$ & $\mathrm{p}_{\mathrm{i} 2}$ & $\mathrm{p}_{\mathrm{i} 3}$ & $\mathrm{p}_{\mathrm{i} 4}$ \\
\hline 1 & 1.7373 & 0.5432 & -0.1909 & -0.7580 & -0.4477 \\
\hline 2 & 0.3410 & 2.1583 & 0.1015 & -0.5056 & -0.2402 \\
\hline 3 & 0.1666 & 0.7186 & 0.5841 & -0.6297 & -0.9278 \\
\hline 4 & -0.3819 & 1.1002 & -0.2924 & 0.0180 & -0.4626 \\
\hline 5 & 0.0531 & 1.2226 & -0.0268 & -0.7651 & 0.5518 \\
\hline 6 & 0.8360 & 0.0076 & 0.0015 & 0.0351 & 0.0003 \\
\hline
\end{tabular}

参考文献

1) Yamashita, T. et al.: Detailed Finite Element Analysis of Composite Beam under Cyclic Load, Journal of Structural and Construction Engineering (Transactions of AIJ), Vol.79, No.704, pp.1481-1490, 2014.10 (in Japanese)

2) Kato, Y.: A study of the prediction method for strong wind around buildings using convolutional neural network, -Wind velocity distribution predication of a building-, Summaries of Technical Papers of Annual Meeting, Architectural Institute of Japan, Structure-I, pp.147-148, 2017.7 (in Japanese)

加藤優輝 : 畳み込みニューラルネットワークを用いたビル風予測手法に 関する研究一単体建物を対象とした風速分布予測一, 日本建築学会大会学 術講演梗概集，構造 I, pp.147-148, 2017.7

3) Tanaka, H. et al.: Optimization Calculations and Machine Learning Aimed at Reduction of Wind Forces Acting on Tall Buildings and Mitigation of Wind Environment, Journal of High-Rise Buildings, 
CTBUH, Vol.8, No.4, pp.291-302, 2019.12

4) Suzuki, T.: Equation Discovery using Mode Extraction via Singular Value Decomposition, Journal of Structural and Construction Engineering (Transactions of AIJ), Vol.86, No.783, pp.838-847, 2021.5(in Japanese)

5) Ministry of Land Infrastructure Transport and Tourism(MILT): Notification No.596 of the Ministry of Land Infrastructure Transport and Tourism, 2007

国土交通省：平成 19 年国土交通省告示第 596 号, 2007

6) Suzuki, T.: Input Motion Inversion in Elasto-plastic Soil Model by Using Modal Iterative Error Correction Method, Journal of Structural and Construction Engineering (Transactions of AIJ), Vol.83, No.749, pp.1021-1029, 2018.7(in Japanese)

7) Suzuki, T.: Improvement of Modal Iterative Error Correction Method using Null Space Modes, Journal of Structural Engineering, Vol.67B, pp.375-382, 2021.3(in Japanese)

8) Suzuki, T.: Mode Selection Method in Modal Iterative Error Correction for Stabilization of Convergence, Journal of Structural and Construction Engineering (Transactions of AIJ), Vol.84, No.756, pp.195-203, 2019.2(in Japanese) 


\title{
EQUATION DISCOVERY FOR SKELTON CURVE OF STEEL BEAM USING NUMERICAL ANALYSIS RESULTS
}

\section{Takuya SUZUKI*1}

\author{
${ }^{*} 1$ Chief Researcher, R\&D Institute, Takenaka Corporation, Dr.Eng.
}

It is important to express the input-output relationship obtained from the numerical analysis using a simplified mathematical expression. However, such research cases are limited to expressions in complicated mathematical expressions, such as neural networks, because these expressions cannot be used with human understanding.

The purpose of this study is to verify the applicability of the equation discovery method to find a simple mathematical expression representing an input/output system of numerical analysis results. For this equation discovery, the method that uses mode extraction via singular value decomposition, as proposed in Reference 4, is used. This method is based on the modal iterative error correction method, which is effective for solving inverse problems with strong discontinuities. Additionally, this method includes a process for removing null modes to obtain a simple equation without unnecessary modes.

In this study, the derivation of equations for the skeleton curve of a steel beam was verified as an example. The outline of the equation discovery method and the example problem are explained first. Then, the equation discovery results are shown, and the applicability of the method is verified.

The key findings of this study are as follows:

(1) Using the numerical analysis results as the training data, the equation for the skeleton curve of the steel beam was derived. Additionally, four kinds of characteristic values, i.e., yield load $Q_{y}$, maximum load $Q_{\max }$, deformation angle at maximum load $\gamma_{\max }$, and load when deformation angle is $1 / 20 \mathrm{rad} Q_{0.05 \mathrm{rad}}$, were deduced. In these equations, shape data of steel beam were used for input parameters. Therefore, a simplified equation consisting of only terms was derived for $Q_{y}, Q_{\max }$ and $Q_{0.05 r a d}$.

(2) The accuracy of the identified equations for the training data was confirmed. Thus, for yield load $Q_{y}$, maximum load $Q_{\max }$, load when deformation angle is $1 / 20 \mathrm{rad} Q_{0.05 r a d}$, the average error rate under approximately $3 \%$, and the accuracy was high. In contrast, regarding deformation angle at maximum load $\gamma_{\max }$, the accuracy decreased with approximately $7 \%$ of the average error rate. And the accuracy of the identified equations for the validation data was confirmed. As the result, it was confirmed that the accuracy for validation data was equivalent to that for the teacher data, and that the overlearning did not occur.

(3) The applicability of the method using "At a deformation angle of $0.03 \mathrm{rad}$ " as the second point was verified. As the result, it was confirmed that the accuracy of the calculation formula of load $Q_{0.03 r a d}$ of "At a deformation angle of 0.03 rad" was high. Using this second point, it becomes possible to avoid the inversion of the skeleton curve. 